\title{
POLA KOMUNIKASI GURU PADA SISWA ANAK BERKEBUTUHAN KHUSUS DI SEKOLAH MENENGAH KEJURUAN INKLUSI
}

\author{
Nuryani, SP. 1, Purwanti Hadisiwi², dan Kismiyati El Karimah² \\ ${ }^{1}$ PT. Pikiran Rakyat Bandung \\ ${ }^{2}$ Universitas Padjadjaran
}

\begin{abstract}
ABSTRAK
Tujuan dari penelitian ini adalah untuk mengetahui faktor apa saja yang mempengaruhi komunikasi guru pada siswa ABK di SMK Balai Perguruan Putri Bandung, bagaimana komunikasi instruksional yang dilakukan guru pada siswa ABK di SMK BPP, dan mengapa sekolah memilih untuk melaksanakan komunikasi pembelajaran yang menggabungkan siswa ABK dan nonABK. Penelitian ini menggunakan tradisi studi kasus dengan metode kualitatif serta menggunakan beberapa teori yang melandasi penelitian yakni teori interaksi simbolik dan teori konvergensi simbolik. Kesimpulan penelitiaan ini adalah 1) beberapa faktor yang mempengaruhi pelaksanaan komunikasi pembelajaran di antaranya kompetensi guru, kesiapan siswa, dan dukungan lingkungan sekolah. Termasuk juga dukungan orang tua dan pendamping. 2) Komunikasi pembelajaran dilaksanakan dalam dua saluran yakni komunikasi pembelajaran di depan kelas dan komunikasi individual antara guru dan siswa. Teknik yang digunakan mulai dari ceramah, tanya jawab, diskusi, demonstrasi, dan juga tutor sebaya. Bahasa verbal dan nonverbal digunakan seperti raut muka ekspresif, suara lantang, artikulasi jelas, gaya tubuh dan bahasa tubuh ekspresif, disertai dengan sentuhan, belaian, tatapan mata. 3) Alasan yang melatar belakangi penyelenggaraan komunikasi instruksional yang menggabungkan siswa ABK dan nonABK di SMK BPP Bandung dilakukan demi kepentingan tiga pihak, yakni siswa ABK, organisasi, serta siswa nonABK.
\end{abstract}

Kata-kata kunci: Komunikasi, instruksional, inklusi, guru, anak berkebutuhan khusus

\section{TEACHER COMMUNICATION PATTERNS TO STUDENT WITH SPECIAL NEEDS IN INCLUSION VOCATIONAL HIGH SCHOOL}

\begin{abstract}
The purpose of the study is to know the background implementation of inclusive education at SMK BPP, the process of instructional communication between teacher and student, and support of the people around disability student to help student study at the class. The method of this research is case study that written in qualitative method and use symbolic interaction theories and symbolic convergence theories. The conclusions of this study are 1) There are several component that influence on implementation instructional communication, such as teachers competence, student, and environment instructional. Include parents and helper. 2) Instructional communication occurs in two channels, instructional communication in front of the class in general and individual instructional communication between teachers and students. Several technique used at the classroom, such as speech technique, question and answer session, discussion, demonstration, and also classmate mentor. Verbal and nonverbal language is used in this communication process, such as expression, strong voice, clear articulation, body styles and expressive body language, accompanied by a touch, caress, and eyes contact. 3) background of the implementation of inclusive education in vocational at SMK BPP Bandung carried out in the interest of the three parties. Disability student, organization, and nondisability student.
\end{abstract}

Keywords: Communication, instructional, inclusive, teacher, disability student

Korespondensi: Nuryani, SP., S.Sos., M.I.Kom. PT. Pikiran Rakyat Bandung. Jl. Asia Afrika No 77 Bandung. Email: nuryanipr@gmail.com 


\section{PENDAHULUAN}

Sekolah Menengah Kejuruan Balai Perguruan Putri (SMK BPP) yang terletak di Jalan Van De Venter Kota Bandung sudah sejak 2004 menjadi sekolah inklusi. SMK ini menjadi satu-satunya SMK di Kota Bandung yang memberikan kesempatan belajar bagi semua anak tanpa kecuali termasukAnak Berkebutuhan Khusus (ABK). Meski menyandang status sebagai sekolah inklusi, tidak satu pun guru di SMK BPP yang saat ini jumlahnya mencapai 48 orang memiliki latar belakang Pendidikan Luar Biasa. Padahal setiap tahun tak kurang dari 10 siswa ABK diterima di sekolah ini, bergabung bersama ratusan siswa lainnya di sejumlah program keahlian. Proses belajar dilaksanakan secara berbaur, bergabung dalam kelas yang sama.

Pada umumnya, siswa ABK mendapat perlakuan khusus dengan tenaga pengajar khusus (setidaknya berlatar belakang pendidikan khusus). Namun, di SMK BPP hal tersebut tak terjadi, karena tak satupun guru di SMK BPP berlatarbelakang pendidikan luar biasa.

$\mathrm{Hj}$. Lina Cuherlinawati ${ }^{1}$ adalah salah satu guru produktif keahlian tata boga yang harus kerja ekstra memberikan pengajaran kepada siswa, siswa ABK dan nonABK. Di dalam kelas, Lina tidak terlihat memberikan perlakuan yang berbeda saat memberikan materi pembelajaran. Instruksi pengajaran yang diberikan pun sama, baik itu kepada siswa nonABK maupun siswa ABK. Untuk memudahkan, Lina menempatkan siswa ABK di jajaran bangku paling depan. Dengan begitu, dia bisa lebih leluasa mengamati, memperhatikan, dan memberikan penjelasan khusus kepada siswa ABK. Terkadang Lina terlihat sedikit berteriak ketika menjelaskan mata pelajaran di dalam kelas. Upaya ini dilakukan untuk memastikan bahwa apa yang dia katakan dan instruksikan bisa dimengerti atau setidaknya didengar oleh semua siswa terutama siswa ABK.

Dalam sebuah kesempatan wawancara, Lina mengakui, tidak mudah memberikan pengajaran secara sekaligus kepada siswa nonABK dan ABK. Karena keduanya memiliki karakteristik berbeda. Apalagi mayoritas siswa ABK di kelasnya adalah mereka yang mengalami kesulitan belajar.

1 Wawancara Tati di SMK BPP (8/7/2014)
Dengan menempatkan siswa ABK di barisan kursi paling depan, Lina berharap apa yang disampaikan bisa lebih mudah dimengerti. Lina pun akan lebih mudah memperhatikan seperti apa respons dari siswa $\mathrm{ABK}$.

Tabel 1 Data Siswa ABK di SMK BPP Kota Bandung.

\begin{tabular}{ccccc}
\hline $\begin{array}{c}\text { Program } \\
\text { Keahlian }\end{array}$ & $\begin{array}{c}\text { Rekayasa } \\
\text { Perangkat } \\
\text { Lunak }\end{array}$ & $\begin{array}{c}\text { Tata } \\
\text { Busana }\end{array}$ & $\begin{array}{c}\text { Tata } \\
\text { Boga }\end{array}$ \\
\hline Siswa ABK & Kelas X & 5 & 1 & 9 \\
& Kelas XI & 3 & 1 & 14 \\
& Kelas XII & 6 & 1 & 9 \\
\hline Jumlah & 49 ABK & 14 & 3 & 32 \\
ABK & & & & \\
\hline
\end{tabular}

Sumber: Bagian Inklusi SMK BPP Kota Bandung

Kepala SMK BPP Tati Rusmiati mengatakan, saat ini ada sekitar 50 siswa ABK yang terdaftar dari sekitar 300 siswa di SMK BPP. Mereka tersebar di beberapa program keahlian. Di SMK BPP ini ada lima program keahlian, yakni tata boga, tata busana, rekayasa perangkat lunak, administrasi perkantoran, dan akomodasi perhotelan. Untuk siswa ABK, sekolah membuka kesempatan belajar di tiga program keahlian, yakni tata boga, tata busana, dan rekayasa perangkat lunak. Tati mengakui semua guru di SMK BPP tidak berlatar belakang pendidikan luar biasa. Pengalaman para guru menjadi salah satu modal utama bagi SMK BPP untuk memberikan layanan inklusi².

Di sini, SMK BPP menjalankan apa yang disebut dengan 'pendidikan untuk semua'. Sejalan dengan apa yang tertulis dalam Undang-Undang Sistem Pendidikan Nasional RI Pasal 5 Ayat 1 UU No 20 Tahun 2003 yang menyebutkan 'Setiap warga negara mempunyai hak yang sama untuk memperoleh pendidikan yang bermutu'. Tak terkecuali bagi Anak Berkebutuhan Khusus (ABK). Di sekolah inklusi seperti inilah kesamaan hak pendidikan anak Indonesia bisa terealisasi.

Dalamberbagaidefinisi, pendidikan inklusi dikatakan sebagai sistem pelayanan pendidikan yang mensyaratkan anak berkebutuhan khusus belajar di sekolah-sekolah terdekat di kelas biasa bersama teman-teman seusianya. Sementara sekolah penyelenggara pendidikan inklusi adalah sekolah yang menampung semua murid di kelas yang sama. Sekolah ini menyediakan program pendidikan yang layak, menantang, tetapi disesuaikan dengan kemampuan dan

$\overline{{ }^{2} \text { Wawancara Tati di SMK BPP }(8 / 7 / 2014)}$ 
kebutuhan setiap murid maupun bantuan dukungan yang dapat diberikan oleh guru agar anak-anak bisa berhasil.

Unesco 2004 (dalam Jamaris, 2014: 221) menyatakan, pendidikan inklusi mengandung pengertian bahwa sekolah perlumengakomodasi kebutuhan pendidikan semua anak dengan tidak menghiraukan kondisi fisik, intelektual, sosial, emosional, bahasa, dan kondisi-kondisi lainnya. Dengan demikian anak-anak normal, anak-anak berkebutuhan khusus, anak-anak dengan latar bahasa dan etnik minoritas, anak-anak jalanan, anak-anak yang bekerja, anak-anak yang berasal dari keluarga yang tidak mampu, anak-anak di daerah terpencil atau anak-anak dari suku yang berpindah-pindah, serta anak-anak yang berasal dari kondisi yang kurang beruntung lainnya perlu mendapat akses terhadap pendidikan.

Peneliti melihat hal ini sebagai hal yang menarik untuk diteliti. Bagaimana guru melakukan komunikasi instruksional kepada siswa ABK sekaligus dengan siswa $\mathrm{ABK}$ dalam waktu dan kelas yang sama. Seperti apa layanan inklusi ini berlangsung di tengah keengganan sekolah lain untuk menerima siswa ABK. Apalagi siswa ABK yang diterima di SMK BPP adalah anak-anak usia sekolah menengah atas yang sudah beranjak dewasa dengan disabilitas yang berbeda-beda. Beragam cerita menarik, pengalaman unik, dan aneka kejadian lucu pun menjadi hal-hal yang bisa diungkap. Bagaimana misalnya ketika guru menerangkan sang siswa malah tertidur pulas. Atau sebaliknya ketika guru menerangkan, siswa ABK justru ingin keluar kelas dan pamit bersalaman kepada semua temannya di kelas.

Sebelum beranjak pada pembahasan selanjutnya, peneliti akan sedikit mengulas mengenai berbagai pengertian komunikasi instruksional yang menjadi fokus penelitian ini. Myers (2010, dalam Raymond dan Lawrence 2014: 312) menyebutkan bahwa bidang komunikasi instruksional merupakan persimpangan antara guru dan siswa, serta pertukaran makna antara guru dan siswa. Sementara itu, McCroskey dan Richmond (2006) meyakini bahwa sebuah keberhasilan dalam komunikasi instruksional tergantung pada keahlian guru, kemampuan pedagogik guru, dan kompetensi guru dalam komunikasi pembelajaran. Dalam hal ini komunikasi instruksional fokus pada proses belajar meng- ajar yang bersifat situasional dalam semua level, seting, atau dalam subjek materi apapun.

Pengertian komunikasi instruksional lainnya yang dikemukakan oleh Lashbrook dan Wheeless (1978) dalam Nimmo (1979: 525). Komunikasi instruksional diartikan sebagai studi komunikasi yang terdiri dari berbagai variabel seperti strategi, proses, teknologi, dan atau suatu sistem yang berhubungan dengan pengajaran formal dan penguasaan materi serta modifikasi hasil belajar (the study of communication variables, strategies, process, technologies and or systems as related to formal instruction and acquisition and modification of learning outcomes). Masih dalam sumber yang sama, Hurt, Scoot and McCroskey menjelaskan bahwa instructional has taken either and application approach or a connective approach, relating various learning theories to more familiar communication research and principles. Dari pernyataan tersebut dapat dijelaskan bahwa instruksional atau pengajaran adalah penerapan pendekatan atau serangkaian pendekatan dalam proses belajar mengajar yang disesuaikan dengan teori-teori belajar yang lebih dikenal dalam prinsip dan penelitian komunikasi.

Sementara itu, Pawit Yusup (1990: 17) mengemukakanbahwakomunikasiinstruksional berarti komunikasi dalam bidang instruksional. Dengan demikian apabila ingin membicarakan tentang komunikasi instruksional, maka dengan sendirinya tidak bisa lepas dari pembahasan mengenai kata atau istilah instruksional itu sendiri. Istilah instruksional berasal dari kata instruction. Ini bisa berarti pengajaran, pelajaran, atau bahkan perintah atau instruksi.

Dalam duniapendidikan, kata instruksional tidak diartikan perintah, tetapi lebih mendekati pengajaran dan atau pelajaran. Atau juga disebut dengan pembelajaran. Istilah pengajaran lebih bermakna pemberian ajar. Mengajar artinya memindahkan sebagian pengetahuan guru pengajar kepada murid-muridnya. Guru dalam konteks komunikasi dianggap sebagai komunikator, atau pemberi pesan, penyampai pesan. Murid dianggap sebagai objek, objek pengajaran atau dalam konteks komunikasi disebut sebagai penerima pesan (Yusup, 1990: 18).

Menurut George Herbert Mead, pikiran manusia mengartikan dan menafsirkan bendabenda dan peristiwa-peristiwa yang dialaminya, menerangkan asal mulanya dan meramalkannya 
(dalam West and Turner, 2009). Dalam teori interaksi simbolik, dijelaskan interaksi yang memunculkan makna khusus dan menimbulkan interpretasi atau penafsiran. Simbolik berasal dari kata 'simbol' yakni tanda yang muncul dari hasil kesepakatan bersama. Bagaimana suatu hal menjadi perspektif bersama, bagaimana suatu tindakan memberi makna-makna khusus yang hanya dipahami oleh orang-orang yang melakukannya.

Mead menyatakan bahwa orang bertindak berdasarkan makna simbolik yang muncul di dalam sebuah situasi tertentu. Simbol sebagai label arbitrer atau representasi fenomena. Simbol membentuk esensi dari teori interaksi simbolik. Teori ini menekankan pada hubungan antara simbol dan interaksi (dalam West and Turner, 2009: 96).

Ralph Larossa dan Donald C Reitzes (1993 dalam West and Turner, 2009: 96) menyatakan bahwa interaksi simbolik pada intinya adalah sebuah kerangka referensi untuk memahami bagaimana manusia, bersama manusia lainnya menciptakan dunia simbolik dan bagaimana dunia ini sebaliknya membentuk perilaku manusia. Dalam pernyataan ini dapat terlihat argumen Mead mengenai saling ketergantungan antara individu dan masyarakat. Nyatanya interaksi simbolik membentuk sebuah jembatan antara teori yang berfokus pada individu dan teori yang berfokus pada kekuatan sosial.

Tiga konsep penting dari interaksi simbolik yang dijabarkan Mead adalah Mind, Self, dan Society. Mead dalam mendefinisikan pikiran sebagai kemampuan untuk menggunakan simbol yang mempunyai makna sosial yang sama, dan Mead percaya bahwa manusia harus mengembangkan pikiran melalui interaksi dengan orang lain (dalam West and Turner, 2009).

Berdasarkan teori ini dapat, setiap aksi dan interaksi antara guru dan siswa ABK dilakukan dengan bahasa, isyarat dan berbagai macam simbol yang muncul akan dapat menimbulkan interpretasi dan pendefenisian dan analisis. Dari prinsip-prinsip dasar teori interaksi simbolik tersebut maka dapat dipahami dengan jelas bahwa proses pemaknaan bukan hanya sematamata dimaknai dengan normatif akan tetapi merupakan hasil dari olah informasi yang di lakukan terus menerus seiring dengan fungsi instrumentalnya.
Teori interaksi simbolik berfokus pada pentingnya membentuk makna bagi perilaku manusia, dimana dalam teori interaksi simbolik tidak bisa dilepaskan dari proses komunikasi. Berdasarkan hal tersebut, peneliti melihat proses komunikasi yang dilakukan guru kepada siswa ABK dapat dikonstruksi secara interpretif oleh individu melalui proses interaksi untuk menciptakan makna yang dapat disepakati secara bersama.

Teori interaksi simbolik juga berfokus pada pentingnya konsep diri. Di mana pengembangan konsep diri seorang $\mathrm{ABK}$ dalam mengikuti proses belajar mengajar di kelas didasarkan pada interaksi sosial antar individu di SMK BPP. Fokus terakhir dari teori interaksi simbolik berkaitan dengan hubungan antara individu dengan masyarakat. Tema ini berkaitan dengan hubungan antara kebebasan individu dan batasan sosial. Asumsi yang berkaitan dengan tema ini adalah orang dan kelompok dipengaruhi oleh proses budaya dan sosial serta struktur sosial dihasilkan melalui interaksi sosial. Asumsi ini mengakui bahwa normanorma sosial membatasi perilaku individu dan struktur sosial tercipta dan berubah karena interaksi manusia. Dalam penelitian ini dapat dilihat bagaimana stigma terhadap siswa ABK di mata guru dan teman sekelasnya. Bagaimana teman-teman sekelasnya dan guru menghadapi dan berinteraksi dengan siswa ABK. Berbagai perilaku yang ditunjukkan siswa $\mathrm{ABK}$ yang mungkin bagi orang lain dianggap aneh, bagi guru dan siswa nonABK di SMK BPP hal tersebut tidaklah menjadi hal yang aneh karena sudah dipahami bersama.

Dalam sejarahnya dua ilmuwan yang memiliki peran besar dalam merintis eksistensi teori konvergensi simbolik yaitu Ernest Bormann dan Robert Bales, di samping dua lainnya yang tidak boleh dilupakan begitu saja yakni John Cragan dan Donald Shield (dalam Littlejohn and Foss, 2008: 162).

Teori Konvergensi Simbolik untuk pertama kalinya diuraikan oleh Bormann dalam tulisannya yang bertajuk "Fantasies and Rhetorical Vision: The Rhetorical Criticism of Social Reality" yang diterbitkan dalam Quartely Journal of Speech tahun 1972. Sejak itu Bormann menulis puluhan artikel dan laporan penelitian yang menggunakan teori ini sebagai landasan teoritisnya dan 
Fantasy Theme Analysis (FTA) sebagai metodenya. Teori Konvergensi Simbolik dari Bormann ini meyakini bahwa "pertukaran fantasi kelompok dapat menciptakan konvergensi simbolik" (Griffin, 2012: 247).

Secara konseptual teori konvergensi simbolik dibangun atas dua istilah (term) yang berbeda. Pertama istilah konvergensi diartikan sebagai suatu cara di mana dunia simbolik pribadi dari dua atau lebih individu saling bertemu, saling mendekati satu sama lain, atau kemudian saling berhimpitan. Kedua istilah simbolik terkait dengan kecenderungan manusia untuk memberikan penafsiran dan menanamkan maknakepada berbagai lambang, tanda, kejadian yang tengah dialami, atau bahkan tindakan yang dilakukan manusia (Venus, 2007: 95).

Ada tiga hal yang membentuk bangunan teori konvergensi simbolik. Pertama penemuan dan penataan bentuk serta pola komunikasi berulang yang mengindikasikan hadirnya kesadaran bersama dalam kelompok secara evolutif.Kedua, deskripsitentangkecenderungan dinamis dalam sistem komunikasi yang menerangkan mengapa kesadaran kelompok muncul, berlanjut, menurun, dan pada akhirnya menghilang. Ketiga, faktor-faktor yang menerangkan mengapa orang-orang terlibat dalam tindakan berbagi fantasi (Venus, 2007: 96).

Dari ketiga bangunan di atas, Bormann menyebutkan dua asumsi pokok yang menjadi landasan dari konvergensi simbolik. Pertama, realitas diciptakan melalui komunikasi. Dalam hal ini komunikasi menciptakan realitas melalui pengaitan antara kata-kata yang digunakan dengan pengalaman atau pengetahuan yang diperoleh. Kedua makna individual terhadap simbol dapat mengalami konvergensi (penyatuan) sehingga menjadi realitas bersama. Sebagai derivasi dari dua asumsi pokok tersebut, Bormann menyebut enam asumsi epistomologis dalam teori ini, yakni: (1) Makna, emosi, dan motif bertindak ada pada isi pesan yang ternyatakan dengan jelas, (2) Realitas diciptakan secara simbolik, (3) Rantai fantasi menciptakan konvergensi simbolik dalam bentuk dramatistik, (4). Analisis tema fantasi adalah metode pokok dalam menangkap realitas simbolik, (5) Tema fantasi dapat terjadi dalam berbagai wacana yang dikembangkan, (6) Terdapat tiga visi analog master, yaitu righteous, social, dan pragmatic (Venus, 2007: 96).

Bormann menyebut metodenya sebagai fantasy theme analysis (analisis tema fantasi) dan ia menerapkannya dalam studi mengenai kelompok-kelompok kecil. (Griffin, 2012: 250). Kemunculan teori konvergensi simbolik diilhami dari hasil riset Robert Bales mengenai komunikasi yang berlangsung dalam kelompokkelompok kecil. Dalam proses riset Bales menemukan kenyataan lain yaitu adanya kecenderungan anggota kelompok menjadi dramatis dan kemudian berbagi cerita ketika kelompok mengalami ketegangan. Ernest Bormann kemudian meminjam gagasan tersebut untuk direplikasikan ke dalam tindakan retoris masyarakat dalam skala yang lebih luas dari sekedar proses komunikasi dalam kelompok (Griffin, 2012: 247).

Dalam pandangan Bales, pada anggota kelompok kecil kerap kali terjadi ketegangan, yang kemudian disiasati dengan cara mendramatisasi untuk melepaskan ketegangan tersebut. Pada saat-saat stres beberapa anggota akan melepaskan ketegangan melalui dramatisasi dan bercerita. Ketegangan dalam kelompok merupakan sesuatu yang wajar, dan ini pada dasarnya terjadi pada seluruh kelompok atau komunitas. Hal ini pula yang menandakan bahwa suatu kelompok berjalan secara dinamis. Cerita-cerita yang disampaikan meliputi lelucon, kisah, ritual, perumpamaan atau permainan kata-kata yang memiliki fungsi mengurangi ketegangan kelompok (tension release), bahkan di sisi lain mampu meningkatkan kesolidan kelompok.

Teori konvergensi simbolik ini dianggap sebagai teori umum dan sudah digunakan dalam penelitian komunikasi terapan. Teori ini berkaitan dengan kecenderungan manusia secara umum untuk menafsirkan dan memberi makna terhadap tanda-tanda dan simbol. Konvergensi mengacu pada cara orang untuk mencoba menyatukan simbol 'dunia' mereka sendiri untuk mencapai apa yang telah digambarkan sebagai 'meeting of the minds' (pertemuan pikiran). Ketika individu berkomunikasi dengan cara sedemikian rupa sehingga simbol 'dunia' mereka pribadi mulai datang secara bersamasama, mereka mulai untuk berbagi sistem simbol. Selama proses konvergensi ini, orangorang akan berbagi tentang fantasi individual mereka. Mimpi dan makna, mereka mulai 
menginterpretasi tanda-tanda dan simbol dalam cara yang sama.

Bormann (1972) menduga, ketika anggota grup berbagi beberapa fantasi dalam waktu tertentu, mereka akan memulai berbagi sosok pahlawan yang sama atau penjahat yang sama, dan kemudian mengelu-elukan sosok atau action yang sama. Grup fantasi ini akan mempermudah proses komunikasi dengan yang lainnya (Infacte, Rancer \& Womack, 1993: 340).

Teori konvergensi simbolik juga meyakini bahwa orang berbagi tipe fantasi tertentu. Berbagi cerita yang sama tapi dengan karakter yang berbeda dan peristiwa yang sedikit berbeda. Bormann (1980) membandingkan jenis fantasi dengan script berulang dalam budaya kelompok (Infacte, Rancer \& Womack, 1993: 340).

Bormann (1980) berargumen bahwa teori konvergensi simbolik merupakan teori komunikasi umum karena melampaui komunitas retoris dan berbagai konteks komunikasi. Pembagian grup fantasi diasumsikan mencakup semua manusia secara kolektif di masa lalu, sekarang, dan di masa depan, terlepas dari perbedaan budaya dan retorika (Infacte, Rancer \& Womack, 1993: 340).

Fungsi dari teori ini adalah menganalisa interaksi yang terjadi di dalam skala kelompok. Kelompok di sini dapat berupa kelompok sosial, kelompok tugas, atau kelompok dalam sebuah pergaulan, bahkan sebuah organisasi. Secara proses, teori ini bertujuan mengetahui bagaimana proses terbentuknya sense of community dan group consciousness dalam sebuah kelompok.

Littlejohn dan Foss menguraikan penerapan tema fantasi dalam skala yang lebih besar. Dalam penerapan teori ini terjadi sedemikian rupa sehingga membentuk elemenelemen yang terdiri dari karakter, alur, tempat, dan perantara pendukung lainnya (2008: 162).

Secara ringkas dapat dikatakan bahwa dalam upaya mengatasi kecemasan, anggota kelompokakan mendramatisir pikiran yang tidak terkait atau ide-ide dan mengaitkannya dengan tugas yang diberikan. Bales mengemukakan bahwa hasil percakapan yang didramatisir terkandung beberapa aspek sebagaimana pada sebuah teater, yaitu pengaturan, karakter, dan tindakan simbolik. Kategori dramatisasi memiliki peranan penting dalam konvergensi simbolik. Dramatisasi berarti melepaskan ketegangan dengan cara menyampaikan cerita dan membagi pengalaman dengan orang lain. Cerita dan pengalaman tidak selalu berhubungan secara langsung dengan kelompok yang bersangkutan.

Bormann menggunakan kata "fantasi" yang mengacu pada "interpretasi yang kreatif dan imajinatif dari sebuah peristiwa yang memenuhi kebutuhan psikologis atau retoris". Dalam latar kelompok kecil, definisi ini meliputi semua referensi yang berkaitan dengan peristiwa-peristiwa di dalam masa lalu kelompok, spekulasi tentang apa yang mungkin terjadi di masa yang akan datang, serta semua pembicaraan mengenai hal-hal di dunia luar kelompok tersebut (Griffin, 2012: 249).

Istilah fantasi ini tidak mencakup tindakan-tindakan yang terjadi "di sini dan sekarang" di dalam kelompok. Fantasi diekspresikan di dalam format kisah narasi, lelucon, metafora, dan bahasa imajinatif lainnya yang menginterpretasikan atau menempatkan hal-hal seputar peristiwa familiar. Fantasi yang diucapkan menjadi kendaraan untuk berbagi pengalaman umum dan menanamkannya dalam nada emosional (Griffin, 2012: 250).

Apakah peristiwa yang dibicarakan benar-benar terjadi atau tidak bukanlah menjadi masalah. Teori Konvergensi Simbolik berfokus pada respons kelompok. Bormann mengatakan bahwa kita dapat menyoroti sebuah reaksi rantai fantasi (fantasy chain reaction) dengan meningkatkan energi di dalam kelompok, dengan cara menaikkan tempo percakapan, dan terutama melalui sebuah respons terhadap perumpamaan. Kebanyakan fantasi tidak menjadi suatu rantai fantasi, melainkan seperti terabaikan begitu saja. Namun ketika satu orang mendapatkan imajinasi mengenai anggota di dalam kelompok tersebut, tema fantasi yang sama dapat terjadi melalui narasi-narasi. Bormann meyakini bahwa dengan berbagi fantasi bersama, sekumpulan individu dapat ditransformasikan ke dalam sebuah kelompok yang kohesif. Ia menyebut proses ini sebagai konvergensi simbolik (Griffin, 2012: 250),

Stephen W. Littlejohn dan Foss dalam Theories of Human Communication menambahkan bahwa cerita atau tema-tema fantasi diciptakan melalui interaksi simbolik dalam kelompok kecil, kemudian dihubungkan dari satu orang ke orang lain dan dari satu 
kelompok ke kelompok lain untuk menciptakan sebuah pandangan dunia yang terbagi (Littlejohn \& Foss, 2008: 165).

Peneliti melihat hal ini sebagai hal yang menarik untuk diteliti. Bagaimana guru melakukan komunikasi instruksional kepada siswa ABK sekaligus dengan siswa ABK dalam waktu dan kelas yang sama. Seperti apa layanan inklusi ini berlangsung di tengah keengganan sekolah lain untuk menerima siswa $\mathrm{ABK}$. Apalagi siswa $\mathrm{ABK}$ yang diterima di SMK BPP adalah anak-anak usia sekolah menengah atas yang sudah beranjak dewasa dengan disabilitas yang berbedabeda. Beragam cerita menarik, pengalaman unik, dan aneka kejadian lucu pun menjadi hal-hal yang bisa diungkap. Bagaimana misalnya ketika guru menerangkan sang siswa malah tertidur pulas. Atau sebaliknya ketika guru menerangkan, siswa ABK justru ingin keluar kelas dan pamit bersalaman kepada semua temannya di kelas.

\section{METODE PENELITIAN}

Metode yang digunakan dalam penelitian ini adalah metode penelitian kualitatif dengan jenis penelitian studi kasus dengan teknik pengumpulan data dengan melakukan wawancara mendalam, observasi dan studi kepustakaan. Wawancara mendalam dilakukan terhadap sejumlah informan yang mencakup guru, kepala sekolah, ketua yayasan, siswa ABK dan siswa nonABK, pendamping, serta orang tua siswa. Observasi dilakukan dengan melihat langsung proses pembelajaran di dalam kelas.

Creswell (2007: 73) menyatakan bahwa studi kasus adalah penelitian yang meliputi studi eksplorasi tentang satu atau beberapa kasus dalam sebuah sistem yang dibatasi (seting, konteks). Stake (dalam Creswell 2007: 73) mengatakan bahwa studi kasus bukanlah metodologi tetapi sebuah pilihan dari apa yang ingin dipelajari (kasus dalam sebuah sistem yang dibatasi), lainnya hadir sebagai strategi penyelidikan, metodologi, atau strategi penelitian yang komprehensif.

\section{HASIL DAN PEMBAHASAN}

Subjek penelitian ini adalah guru SMK $\mathrm{BPP}$, tiga guru menjadi informan kunci yakni Lina Cuherlinawati, Veni Octaviani, Gita Rahmawati. Serta dua informan kunci lainnya yakni Kepala Sekolah Tati Rusmiati dan Ketua Yayasan BPP Sofia Kartawijaya. Selain itu ada beberapa informan pendukung untuk melengkapi data untuk menunjang penelitian. Yakni Kepala Bidang Pendidkan SMA/SMK Dinas Pendidikan Kota Bandung Dedi Darmawan, salah satu siswa ABK yang masih bisa diajak berkomunikasi yakni Jidan, salah satu teman sekelas (siswa nonABK) Jasmin, seorang helper atau pendamping ABK Robiansyah, dan salah satu orang tua $\mathrm{ABK}$ Nurhasanah.

Faktor yang mempengaruhi komunikasi pembelajaran di kelas, Guru di kelas menjadi salah satu faktor utama dalam pelaksanaan komunikasi instruksional pada siswa $\mathrm{ABK}$ di kelas. Kompetensi guru, kemampuan guru untuk ber-komunikasi, dan gaya komunikasi verbal dan nonverbal guru menjadi beberapa elemen utama yang menentukan komunikasi instruksional yang berlangsung di kelas.

Menurut Ketua Yayasan BPP Sofia, kompetensi guru memang penting. Namun, kompetensi dalam hal pendidikan yang dimiliki guru bukan menjadi hal yang utama. Sofia justru melihat hal lain yang harus dimiliki yakni nurani dan perasaan humanis guru terhadap siswa ABK. Ketika guru mengajar dengan hati, maka kegiatan belajar akan jauh lebih mudah dan menyenangkan bagi siswa.

"Terutama gurunya, makanya sejak awal kami tekankan guru agar mengajar dengan hati dengan perasaan, meskipun di sini guru tidak ada yang berlatar belakang pendidikan luar biasa, tapi pengalaman dan hati nurani yang dimiliki guru menjadi modal utama dalam memberikan pengajaran kepada mereka," 3

Faktor selanjutnya yang juga sangat menentukan adalah siswanya sendiri. Apalagi untuk siswa $\mathrm{ABK}$ yang memiliki keterbatasan dalam berkomunikasi dan menangkap pesan yang disampaikan guru. Siswa harus benarbenar dipastikan dalam kondisi siap menerima informasi dan pesan yang akan disampaikan guru. Di sini gurulah yang dituntut untuk memahami dan mengetahui secara pasti kapan

\footnotetext{
${ }^{3}$ Wawancara Sofia di SMK BPP 19 Maret 2015
} 
waktu yang tepat siswa $\mathrm{ABK}$ bisa menerima pesan dan berkomunikasi dengan guru di kelas.

Kepala Sekolah Tati menyebutkan, guru-guru harus memiliki keahlian untuk melihat kondisi kesiapan siswa dalam mengikuti pelajaran dan menerima pesan saat berkomunikasi. Guru harus tahu kapan waktu yang tepat untuk bisa berkomunikasi dan menyampaikan materi kepada siswa.

Faktor kesiapan siswa dalam menerima materi pelajaran juga disampaikan Robi sebagai helper. Sebagai guru pendamping khusus, Robi hafal betul kapan waktunya guru bisa berkomunikasi dengan siswa $\mathrm{ABK}$ terutama autis. Robi menjelaskan ciri-ciri anak yang siap diajak berkomunikasi adalah ketika anak kontak mata dengan lawan bicaranya. Di saat itulah kesempatan guru untuk berkomunikasi dan menyampaikan pesan yang ingin disampaikan. Sebab jika tidak dalam kondisi siap menerima pesan, maka pesan apapun yang diberikan tidak akan masuk. Untuk anak autis seperti Jidan misalnya, guru atau siapapun yang ingin berkomunikasi dengan Jidan harus memastikan Jidan dalam kondisi siap berkomunikasi dan menerima informasi. Yakni saat mata Jid terfokus kepada lawan bicara. Harus dipastikan Jidan melihat langsung mata si pembicara sehingga dia mendengar dan memperhatikan pesan yang disampaikan.

"Kesulitan belajarnya karena matanya harus kontak, kesempatan untuk memberikan pesan adalah pada saat kontak mata, matanya benar-benar harus melihat kita berbicara. Kalau tidak ya tidak akan didengar," 4

Ada banyak faktor yang turut menentukan dalam pelaksanaan komunikasi pembelajaran di kelas. Selain guru dan siswa, faktor lainnya seperti orang-orang di sekitar siswa ABK juga ikut menentukan. Di antaranya adalah teman sebaya atau teman sekelas siswa ABK. Dari hasil penelitian diketahui peran dari orangorang sekitar mampu membantu siswa $\mathrm{ABK}$ dalam proses pembelajarannya. Termasuk juga helper atau pendamping siswa ABK serta orang tua di rumah.

Dari hasil wawancara tersebut ada beberapa faktor yang bisa dirumuskan dalam penelitian ini:

\footnotetext{
${ }^{4}$ Wawancara Robiansyah di SMK BPP 9 Februari 2015
}

Guru, kompetensi guru di sini bukan berarti kompetensi dalam bentuk formil berupa latar belakang pendidikan guru. Namun lebih kepada pengalaman dan kemampuan guru untuk bisa berkomunikasi dengan siswa ABK dengan hati nurani dan perasaan atau pendekatan humanis. Di sini kemampuan guru dalam berkomunikasi menjadi faktor utama.

Siswa ABK sendiri. Keberhasilan dari pelaksanaan komunikasi instruksional di kelas sangat tergantung dari siswanya sendiri. Ketika siswa tidak berada dalam mood yang baik maka guru akan sulit berkomunikasi. Harus dipastikan suasana hati siswa $\mathrm{ABK}$ cukup baik untuk menerima pesan atau materi pembelajaran dari guru. Karena karakteristiknya khusus, maka guru yang harus bisa mengenal dan memahami semua siswanya satu per satu. Guru harus tahu kapan saat yang tepat untuk bisa berkomunikasi dengan siswa $\mathrm{ABK}$.

Lingkungan sekolah. Di antaranya adalah orang-orang yang ada di lingkungan sekolah, seperti teman sekelas, guru-guru di sekolah, serta keberterimaan dari lembaga beserta seluruh elemennya. Teman sekelas yang sebaya bisa membantu proses komunikasi pembelajaran di kelas. Membuat ABK mampu bersosialisasi dan berkomunikasi termasuk membantu guru dalam melaksanakan proses pembelajaran. Siswa nonABK yang sudah kenal dekat dengan siswa ABK dianggap lebih memahami siswa ABK sehingga dengan pendekatan teman sebaya, siswa ABK lebih mudah menerima pesan. Dalam beberapa mata pelajaran, pemahaman $\mathrm{ABK}$ bisa terbantu oleh teman sekelasnya.

Helper atau pendamping menjadi faktor utama lainnya. Tidak semua ABK di SMK BPP didampingi helper. Siswa ABK yang didampingi helper memiliki kemandirian yang lebih baik. Helper menerapkan kedisiplinan yang cukup tegas terhadap ABK melalui berbagai perjanjian atau komitmen yang dibangun. Salah satunya untuk mau mengikuti pelajaran di kelas ketika ada guru di dalam kelas.

Orang tua ABK. Sekolah menyatakan bahwa peran terpenting dari keberhasilan pembelajaran di sekolah adalah orang tua. Karena di rumahlah ABK lebih banyak menghabiskan waktu dan orang tua yang 


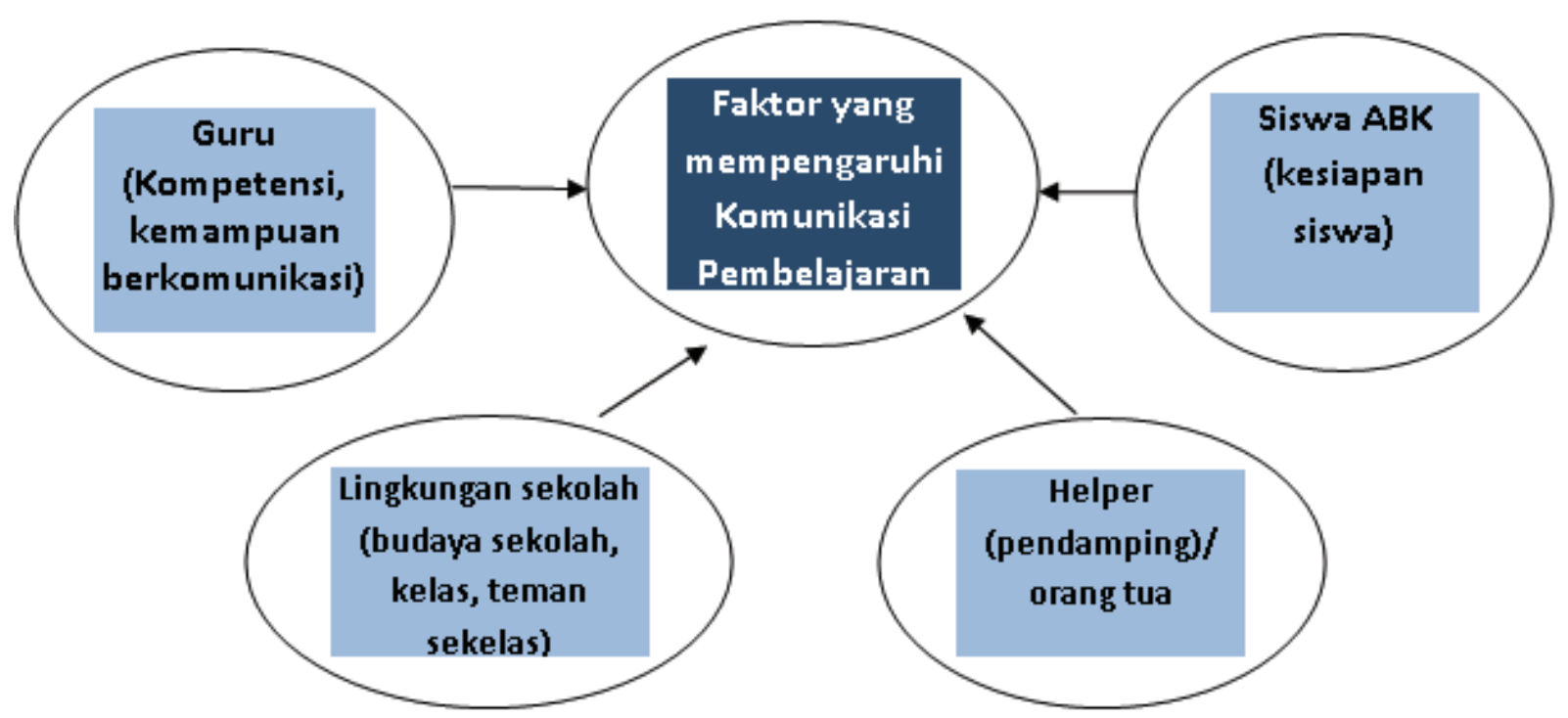

Sumber: Data Hasil Penelitian, 2016

\section{Gambar 1 Faktor yang Mempengaruhi Komunikasi Instruksional}

mampu melatih anak-anaknya yang memiliki keterbatasan inilah yang bisa membentuk ABK yang mandiri. Orang tua berperan besar dalam menjadikan ABK mandiri dalam melaksanakan dan memenuhi kebutuhan pribadi seperti makan, ke kamar kecil, atau ibadah. Skill yang diajarkan di sekolah akan lebih terasah ketika dilatih juga oleh orang tua di rumah termasuk dalam hal pengerjaan tugas-tugas sekolah yang harus diselesaikan di rumah. Orang tua juga membantu menanamkan pemahaman mengenai kedisiplinan untuk mengikuti proses pembelajaran di kelas.

Berdasarkan hasil penelitian tersebut, peneliti menggambarkan beberapa faktor yang mempengaruhi komunikasi pembelajaran siswa di kelas sebagai berikut

Komunikasi pembelajaran guru dan siswa ABK dipengaruhi oleh banyak hal. McCroskey merinci setidaknya ada enam komponen penting dalam model komunikasi instruksional, yakni guru, siswa, lingkungan, perilaku komunikasi verbal dan nonverbal guru, persepsi siswa terhadap guru, dan hasil belajar. Tiga yang pertama yakni guru, siswa, dan lingkungan dianggap menjadi elemen utama dalam komunikasi instruksional.

Guru sebagai pemeran utama dari proses komunikasi instruksional ini. Berbagai aspek dalam diri guru berperan besar dalam sebuah proses komunikasi instruksional di kelas, mulai dari tingkat kecerdasan guru, pengetahuan guru akan konten pembelajaran, pengetahuan pada pedagogis, kompetensi komunikasi, serta pengalaman guru yang juga penting. Selain di dalamnya ada unsur pendidikan guru, kepribadian, dan temperamental. Semua elemen ini mempengaruhi pilihan guru dalam berperilaku baik komunikasi verbal dan nonverbal di dalam komunikasi pembelajaran.

Dalam hasil penelitian ini, peneliti melihat dari segi kompetensi guru, tidak lagi penting latar belakang guru dalam hal pendidikan. Sebab semua tenaga pengajar di SMK BPP tidak ada yang berlatar belakang pendidikan luar biasa. Padahal dalam menangani anak berkebutuhan khusus diperlukan perlakuan dan komunikasi yang berbeda. Di sini guru menggunakan hati nurani dalam mengajar dan berkomunikasi dengan siswa ABK. Bertindak humanis dengan menganggap anak-anak spesial ini seperti anak sendiri. Dari situ timbul ketulusan dalam mengajar sehingga siswa ABK merasa nyaman meski dari segi akademik tidak mungkin siswa ABK bisa mengejar akademik yang tercantum dalam kurikulum. Pengalaman dalammenangani ABK menjadi modal utama SMK BPP untuk bisa menyelenggarakan pendidikan inklusi di mana komunikasi pembelajaran di kelas digabungkan antara siswa ABK dan nonABK. Meskipun tak ada kompetensi khusus, fasilitas khusus, atau penunjang khusus bagi siswa ABK di SMK BPP.

Salah satu asumsi dari teori interaksi simbolik adalah pentingnya makna bagi perilaku manusia. Teori ini berpegang bahwa individu membentuk makna melalui proses komunikasi. Dibutuhkan konstruksi interpretif di antara 
orang-orang untuk menciptakan makna. Bahkan tujuan untuk berinteraksi adalah menciptakan makna.

Di sini guru-guru SMK BPP memaknai siswa ABK sebagai siswa yang memiliki hak dan posisi yang sama di SMK BPP. Mereka berhak dilayani dan mendapat perlakuan yang sama dengan siswa lainnya. Meski dengan berbagai keterbatasan yang dimiliki oleh siswa ABK. Mead juga berpegang bahwa makna yang diberikan pada simbol merupakan produk dari interaksi sosial yang menggambarkan kesepakatan bersama untuk menerapkan makna tertentu pada simbol tertentu pula (dalam West and Turner, 2009). Dalam penelitian ini, simbol-simbol yang ditunjukkan oleh siswa ABK memberikan makna yang disepakati bersama oleh seluruh elemen di sekolah terutama guru. Guru harus memahami simbolsimbol yang ditunjukkan oleh siswa ABK untuk mempermudah komunikasi pembelajaran di kelas. Ketika siswa mulai melakukan aktivitas yang mengganggu seperti memukul meja, mengganggu temannya dan aktivitas aneh lainnya, ini dimaknai oleh guru bahwa siswa ABK tersebut sudah jenuh dan bosan di kelas. Guru harus jeli dan melakukan upaya membujuk atau menciptakan suasana kelas yang menyenangkan.

Pola komunikasi instruksional guru pada siswa ABK di BPP. Komunikasi instruksional di sini tidak diartikan perintah, tetapi pengajaran atau pembelajaran. Yang artinya memindahkan sebagian pengetahuan guru pengajar kepada murid-muridnya. Tujuannya dari komunikasi instruksional ini adalah perubahan sikap dan tingkah laku yang positif dari peserta didik setelah mengikuti kegiatan belajar mengajar.

Proses komunikasi instruksional yang berlangsung antara guru di SMK BPP dengan siswa ABK berbeda dengan komunikasi instruksional guru dengan siswa nonABK. Komunikasi nonverbal yang mengandalkan bahasa tubuh dan simbol-simbol nonverbal lainnya menjadi unsur penting dalam komunikasi antara guru dan siswa ABK.

Komunikasi yang berlangsung antara guru dengan siswa ABK yang satu dengan siswa $A B K$ yang lainnya pun berbeda-beda. Sebab karakteristik siswa ABK di SMK BPP ini berbeda-beda. Meskipun secara umum jika dilihat berdasarkan observasi peneliti di lapangan tidak ada perbedaan berarti dalam proses pembelajaran antara siswa nonABK dengan siswa ABK terutama pada saat guru menyampaikan materi pembelajaran di depan kelas. Metode yang digunakan guru saat menyampaikan materi di depan kelas mayoritas berupa ceramah. Selain itu diterapkan juga metode demonstrasi terutama saat komunikasi pembelajaran berlangsung di kelas praktikum program keahlian.

Di SMK BPP, setiap guru memiliki cara masing-masing untuk dapat berkomunikasi dengan setiap siswa ABK. Guru pada umumnya terlebih dahulu melakukan pendekatan secara khusus, mulai dari pendekatan yang bersifat administratif yakni dengan melihat biodata siswa ABK. Mendalami latar belakang keluarga, sekolah terdahulu, serta riwayat kesehatan dari ABK saat siswa mendaftar pertama kali. Ataupun melalui pendekatan khusus secara personal ketika siswa $\mathrm{ABK}$ mulai masuk sekolah.

Pendekatan seperti ini memang dilakukan oleh pihak sekolah dan sudah menjadi prosedur tetap yang diberlakukan sebelum proses pembelajaran dimulai saat tahun ajaran baru datang. Pihak sekolah biasanya mendata secara khusus siswa-siswa ABK yang mendaftar dan yang diterima di sekolah tersebut. Komunikasi khusus dengan orang tua $\mathrm{ABK}$ pun dilakukan untuk bisa menggali informasi terkait siswa ABK. Ini akan memudahkan guru-guru di sekolah untuk menangani siswa $\mathrm{ABK}$ di kelas.

Menurut Kepala SMK BPP Tati Rusmiati, seluruh guru di SMK BPP dituntut harus mengenal siswanya terlebih dahulu. Sebab jika hal ini tidak dilakukan maka akan banyak kendala ketika proses pembelajaran mulai berjalan.

"Jadi kalau mendidik itu harus mengerti dulu latar belakangnya, kebiasaan anak di rumah bagaimana, apa yang jadi pobia anak, ya jangan di sini diberikan. Harus kenal anak. Guru tidak boleh tidak tahu, harus tahu, keadaan anak, sifat anak itu, trauma anak, dan kemampuan anak, sehingga tidak jadi beban guru, karena kalau dipaksakan bisa stres dua-duanya. Baik itu guru ataupun anaknya,",

Meski demikian, Tati mengaku tak ada

${ }^{5}$ Wawancara Tati Rusmiati di SMK BPP 9 Februari 2015 
metode khusus yang digunakan untuk berkomunikasi dengan siswa ABK ini. Guru-guru hanya diminta menggunakan hati nurani dalam memberikan pengajaran kepada siswa ABK. Tanpa mengesampingkan pembelajaran kepada siswa nonABK, artinya keduanya harus seimbang meski siswa ABK memerlukan perhatian lebih.

Fleksibilitas menjadi hal yang diutamakan oleh setiap guru dalam berkomunikasi dan memberikan pengajaran. Mengingat setiap anak terutama $\mathrm{ABK}$ memiliki karakteristik yang berbeda-beda sehingga perlakuan yang diberikan pun akan berbeda antara satu anak dengan anak lainnya.

Guru lainnya, Lina Cuherlinawati lebih mengandalkan pengalaman pribadinya saat berkomunikasi di kelas. Pengalaman sebagai guru Bimbingan Konseling sekaligus sebagai orang tua $\mathrm{ABK}$ membuat Lina cukup piawai dalam menangani dan berkomunikasi dengan siswa ABK. Meskipun dari segi pemberian materi, Lina pun mengakui cukup sulit memberikan materi dengan porsi yang sama kepada siswa ABK seperti halnya kepada siswa nonABK.

"Di lingkungan keluarga saya ada anak saya sendiri adalah siswa ABK yakni punya kelainan tulang jadi hanya bisa menggunakan kursi roda. Makanya saya memilih mengajar di SMK BPP karena sensitifitasnya sudah terbangun sejak saya memiliki anak yang bernasib sama dengan mereka. Sensitifitas ini membuat saya lebih mengerti mereka, seperti ke anak sendiri. Saya juga lebih paham kapan siswa merasa siap di kelas dan seperti apa ketika mereka jenuh, walaupun tetap kalau untuk materi tidak akan bisa mengejar," 6

Bagi Lina, yang terpenting dalam keberhasilan komunikasi pembelajaran di kelas bukanlah ukuran materi dan seberapa banyak pesan yang bisa diterima oleh siswa $\mathrm{ABK}$. Tapi bagaimana dia bisa bersosialisasi dengan siswa nonABK serta bagaimana agar siswa ABK bisa menjadi lebih mandiri. Tak ada metode khusus dan media khusus yang dipakai Lina dalam memberikan pengajaran di kelas. Semuanya dilakukan secara alamiah dan hanya

\footnotetext{
${ }^{6}$ Wawancara dengan Lina Cuherlinawati di SMK BPP 9 Februari 2015
}

mengandalkan perasaan.

"Siswa dalam sistem pembelajarannya memang belum sesuai apalagi karena di kita belum ada pengajarkhusus untuk siswa $\mathrm{ABK}$, yang lebih bermanfaat di sisi lainnya mungkin seperti dari sisi sosialisasinya, kemudian anak-anak jadi lebih mandiri melalui berbagai jurusannnya. Itu yang bisa kita ajarkan. Kalau pengajar khusus kita tidak punya, metode khusus juga tidak ada jadi lebih banyak umum saja. Saya menyampaikan materi di depan kelas seperti biasa, memang harus ekspresif, kita harus aktif, kadang saya sambil tepuk tangan supaya anak-anak memperhatikan. Atau ber-cerita dulu yang lucu-lucu supaya anak-anak semangat,"

Berdasarkan hasil wawancara yang dilakukan peneliti terhadap beberapa informan, pelaksanaan komunikasi instruksional yang dilakukan guru dapat diuraikan sebagai berikut: (1) Komunikasi pembelajaran di depan kelas dengan metode ceramah, diskusi kelas, dan tanya jawab. Di sini guru berkomunikasi kepada siswa ABK dan nonABK sekaligus. Siswa ABK maupun nonABK memperoleh pesan yang sama. Komunikatornya adalah guru, guru dituntut lebih sensitif, mampu memahami setiap karakter siswa terutama siswa ABK agar komunikasi bisa berjalan. Siswa sebagai komunikan. Bentuk komunikasi verbal dan nonverbal dilakukan oleh guru dalam komunikasi pembelajaran di depan kelas. Verbal berupa pesan-pesan materi pembelajaran yang disampaikan guru dalam bahasa yang sederhana sehingga mudah dimengerti oleh siswa $\mathrm{ABK}$ dan juga nonABK dengan artikulasi yang jelas, suara yang lantang, serta melalui mimik muka yang ekspresif cenderung 'centil'. Komunikasi nonverbal dilakukan melalui gaya tubuh, bahasa tubuh, serta gerakan-gerakan yang mendukung pesan agar semakin mudah dimengerti oleh anak. Pesan yang dikomunikasikan guru saat di depan kelas adalah materi pembelajaran sesuai dengan mata pelajaran yang diampu oleh guru. Saluran komunikasinya tatap muka dan sedapat mungkin berinteraksi dengan semua siswa. Media yang digunakan adalah papan tulis dan buku. Di sini guru tidak menggunakan media pembelajaran atau fasilitas khusus lain. Selain karena keterbatasan fasilitas yang ada ${ }^{7}$ Wawancara dengan Lina Cuherlinawati di SMK BPP 9 Februari 2015 
di sekolah, guru juga menganggap dengan berkomunikasi langsung, bertutur dan menulis di papan tulis sudah cukup untuk melaksanakan pembelajaran di kelas. Efeknya membuat siswa bisa menerima pesan yang disampaikan dan mampu memahami materi yang disampaikan guru di depan kelas. (2) Komunikasi secara individual face to face satupersatuantaragurudan siswa ABK. Komunikasi ini dilakukan setelah guru selesai memberikan materi kepada siswa di depan kelas. Setelah memberi kesempatan kepada siswa untuk bertanya, guru memberikan tugas kepada siswa untuk dikerjakan. Pada saat inilah komunikasi individual satu per satu berlangsung antara guru dengan siswa ABK. Komunikatornya adalah guru. Sebisa mungkin guru menempatkan diri sebagai teman bahkan orang tua yang menyayangi siswa $\mathrm{ABK}$ seperti anaknya. Kedekatan dan rasa percaya yang muncul dari siswa akan mempermudah proses komunikasi berlangsung. Komunikannya adalah siswa ABK. Bentuk komunikasi verbal dan nonverbal dilakukan guru kepada siswa ABK. Verbal melalui kata-kata yang disampaikan guru terkait materi yang sebelumnya disampaikan di depan kelas disertai pujian, dorongan semangat, dan ajakan agar siswa mau mengikuti arahan guru. Sementara komunikasi nonverbal dilakukan melalui tatapan mata, belaian, sentuhan, dan kasih sayang guru kepada siswa $A B K$ agar $A B K$ nyaman. Di sini guru juga menyisipkan cerita-cerita yang bisa memotivasi siswa untuk terus belajar. Guru berusaha membangkitkan kepercayaan diri siswa dengan pujian dan penghargaan ketika siswa dianggap mampu melakukan instruksi yang diberikan guru. Pesan yang disampaikan adalah materi pembelajaran selain kata-kata bujukan (persuasive) untuk membujuk siswa ABK mengerjakan sesuatu. Pujian serta motivasi agar siswa lebih percaya diri. Saluran komunikasi tatap muka dengan interaksi secara dua arah antara guru dengan siswa ABK. Efeknya, siswa ABK merasa nyaman, dan mampu menerima pesan yang disam-paikan guru dan lebih jauh lagi bisa melaksanakan apa yang diperintahkan. (3) Teknik yang digunakan guru selain ceramah juga diskusi kelas, tanya jawab. Guru juga menggunakan teknik tutor sebaya dengan memanfaatkan teman sekelas siswa ABK yang dianggap mahir dan bisa membimbing siswa ABK.

Berdasarkan hasil penelitian tersebut, peneliti menggambarkan komunikasi instruksional guru pada siswa ABK dalam bagan sebagai berikut:

Komunikasi instruksional berlangsung melalui komunikasi verbal maupun nonverbal juga melalui simbol-simbol tertentu yang di tunjukkan oleh siswa $\mathrm{ABK}$ dan dipahami oleh guru dan orang-orang di sekeliling $\mathrm{ABK}$. Dalam proses komunikasi juga terjadi pertukaran simbol-simbol terutama simbol yang diperlihatkan oleh siswa ABK. Guru harus benarbenar memahami simbol yang ditunjukkan siswa ABK berikut maknanya. Untuk berkomunikasi, harus dipastikan guru melakukan kontak mata dengan siswa ABK terutama ABK autis. Simbol kontak mata ini menjadi simbol yang dipahami bersama oleh seluruh anggota kelompok di SMK

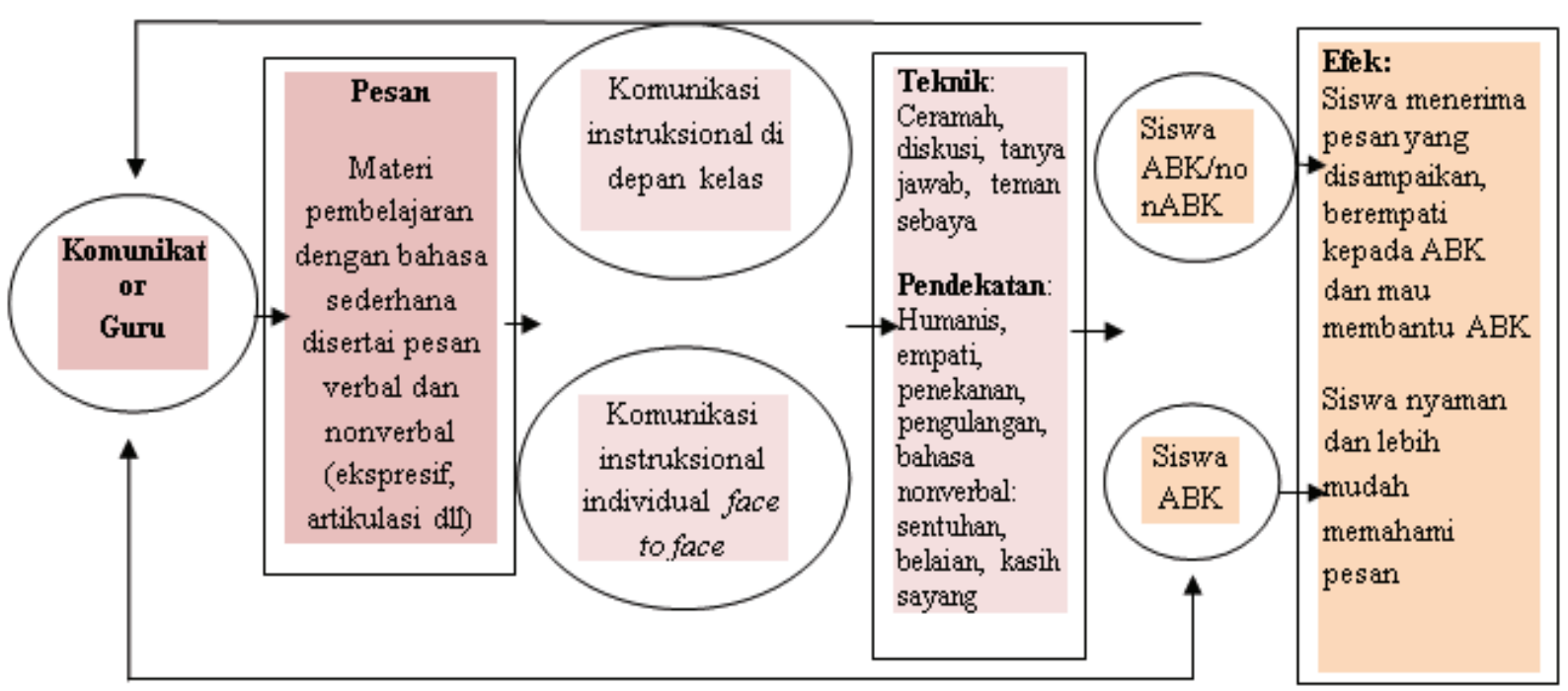

Sumber: Data Hasil Penelitian, 2016

Gambar 2 Pola Komunikasi Instruksional Guru Pada Siswa ABK 
BPP. Karena tanpa kontak mata pesan yang disampaikan guru tidak akan diterima siswa. Simbol lainnya di antaranya adalah perilaku ABK yang menunjukkan ketidaknyamanan di kelas. Misalnya saat siswa mulai mengganggu temannya, atau berteriak dan memukul bangku. Dalam kondisi ini guru harus bisa memberi keleluasaan kepada siswa. Membiarkan siswa keluar kelas sesaat agar siswa tidak jenuh.

Dalam komunikasi instruksional yang berlangsung, guru-guru menggunakan pendekatan humanis di dalam pendidikan dan pembelajaran. Dalam pendekatan humanis ini, guru harus mampu mengembangkan perasaan positif siswa terhadap dirinya sendiri yang diarahkan pada pengembangan kepribadian yang positif. Kepribadian positif selanjutnya akan mendukung proses pendidikan dan pembelajaran yang dijalani oleh siswa tersebut. Tak hanya terhadap siswa $\mathrm{ABK}$, pengembangan perasaan positif juga harus diberikan kepada siswa nonABK. Karena dengan perasaan positif, siswa nonABK diarahkan untuk menghargai orang lain tanpa membedakan asal-usul, ras, latar belakang sosial, dan ekonomi serta agama.

Jika dilihat dari teori interaksi simbolik, komunikasi yang dilakukan dalam layanan inklusi ini pada dasarnya merupakan proses pertukaran simbol-simbol bermakna. Simbolik berasal dari kata simbol yakni tanda yang muncul dari hasil kesepakatan bersama. Bagaimana suatu hal menjadi perspektif bersama, bagaimana suatu tindakan memberi makna-makna khusus yang hanya dimengerti oleh orang-orang yang melakukannya. Dalam penelitian ini simbol yang muncul terutama yang berasal dari siswa $\mathrm{ABK}$ dan persepsi mengenai siswa $\mathrm{ABK}$ serta bagaimana selanjutnya guru serta siswa nonABK melihat siswa $\mathrm{ABK}$ ini dalam berinteraksi satu sama lain.

Mead sebagai peletak dasar teori interaksi simbolik berasumsi bahwa manusia melakukan aktivitas yang menjadi ciri khas manusia yaitu komunikasi pertukaran simbol (dalam West and Turner, 2009). Komunikasi dilakukan oleh guru dan siswa ABK dengan demikian terjadi proses pertukaran simbol. Sesuai dengan pemikiran Mead, salah satu ide dasar teori interaksi simbolik adalah mind (pikiran) di mana Mead mengartikan sebagai kemampuan untuk menggunakan simbol yang mempunyai makna sosial yang sama di mana setiap individu harus mengembangkan pikiran mereka melalui interaksi dengan individu lain. Agar mempunyai makna sosial yang sama, individu harus melakukan interaksi dengan individu lainnya yakni melalui proses komunikasi (dalam West and Turner, 2009).

Berdasarkan observasi dan wawancara yang dilakukan peneliti, komunikasi instruksional yang berlangsung antara guru dan siswa ABK di SMK BPP berlangsung setidaknya dalam dua proses. Pertama komunikasi secara kelompok di mana guru menyampaikan pesan berupa materi pembelajaran di kelas bersamaan dengan siswa nonABK. Metode yang digunakan dalam proses ini adalah metode ceramah dan tanya jawab. Metode demonstrasi juga digunakan guru terutama saat melakukan komunikasi pembelajaran di kelas praktikum. Biasanya guru mencontohkan terlebih dahulu dengan mempraktikannya menggunakan media yang ada seperti peralatan memasak dan bahanbahan masakan yang sudah disediakan.

Setelah proses komunikasi di depan kelas selesai atau tuntas, selanjutnya guru melakukan komunikasi instruksional secara individual dengan siswa ABK. Pesan yang disampaikan adalah materi yang sebelumnya di berikan di depankelas dengan penekanan dan pengulangan. Di dalam proses ini lebih kepada diskusi dan upaya persuasif guru dalam menyampaikan pesan materi pembelajaran.

Dalam proses komunikasi pembelajaran ini guru tidak hanya mengajar berdasarkan apa yang ada di dalam pikirannya. Guru juga berusaha menempatkan diri dalam diri siswa. Sensitifitas guru yang mengarahkan hal ini, dengan mencoba merasakan apa yang siswa rasakan. Selain juga mencoba memposisikan diri sebagai teman bahkan orang tua dari siswa ABK.

Konsep penting Mead dalam teori interaksi simbolik adalah pikiran (mind), pemikiran (thought), dan aktifitas selanjutnya adalah pengambilan peran (role taking). Pikiran diartikan sebagai kemampuan untuk meng-gunakan simbol yang mempunyai makna sosial yang sama, kemudian pemikiran yang diartikan sebagai percakapan di dalam diri sendiri, dan pengambilan peran atau kemampuan untuk secara simbolik menempatkan dirinya sendiri dalam diri khayalan orang lain (dalam West and Turner, 2009).

Guru di SMK BPP menggunakan sensi- 
tifitas dan nalurinya untuk melakukan hal ini. Pikiran mereka terhadap keberadaan siswa ABK yang sudah dianggap seperti anak sendiri memunculkan pemikiran yakni percakapan di dalam diri sendiri yang ingin selalu berusaha untuk bisa memberikan yang terbaik bagi anak. Guru mencoba memposisikan sebagai siswa ABK yang memilikiketerbatasan. Dengan begitu guru bisa mengetahui apa saja yang menjadi kelemahan dari siswa ABK sehingga guru lebih tahu bagaimana cara mengatasinya dan apa yang harus dilakukan untuk meminimalisir kelemahan tersebut.

Mead menyebutkan bahwa proses role taking atau pengambilan peran disebut juga pengambilan perspektif karena kondisi ini mensyaratkan bahwa seseorang menghentikan perspektif dirinya sendiri terhadap sebuah pengalaman dan sebaliknya membayangkannya dari perspektif orang lain. Mead menyatakan bahwa pengambilan peran adalah sebuah tindakan simbolis yang dapat membantu menjelaskan perasaan kita mengenai diri dan juga memungkinkankita untukmengembangkan kapasitas untuk berempati dengan orang lain (dalam West and Turner, 2009).

Ketika guru menempatkan diri pada posisi siswa $\mathrm{ABK}$, guru akan merasakan bagaimana sulitnya siswa $\mathrm{ABK}$ ikut dalam proses kegiatan belajar mengajar yang kurikulumnya sama dengan siswa nonABK. Dengan begitu guru bisa bersikap lebih fleksibel terhadap siswa ABK dengan menurunkan standar ketuntasan disesuaikan dengan kemampuan siswa ABK. Tidak ada standar khusus bagi siswa ABK, semuanya disesuaikan dengan masing-masing siswa $A B K$. Artinya antara satu siswa $A B K$ dengan ABK lainnya akan berbeda pula standar ketuntasannya. Guru pun lebih berempati kepada siswanya karena memahami posisi siswa ABK. Dalam berkomunikasi guru lebih bersabar, lebih menunjukkan rasa kasih sayang, dengan belaian, sentuhan, memberikan pujian dan penghargaan terhadap apa yang dilakukan ABK. Dengan cara berkomunikasi seperti ini, siswa ABK menjadi lebih nyaman dan lebih tenang sehingga mudah untuk mengikuti proses pembelajaran di kelas. Meskipun dari segi capaian akademik tetap tidak akan bisa menyamai siswa reguler. Namun setidaknya, bagi guru, siswa bisa lebih bersosialisasi, mau berkomunikasi, dan bisa lebih mandiri berkat dukungan dari orang-orang yang ada di sekitar ABK.

Peneliti juga melihat guru melakukan berbagai strategi dan upaya untuk mengefektifkan proses komunikasi instruksional di kelas. Profesionalisme sebagai guru pengampu program keahlian ditunjukkan secara humanis oleh guru di SMK BPP. Strategi seperti ceramah, diskusi di kelas, kerja kelompok sampai dengan penggunaan tutor sebaya digunakan oleh pengajar untuk mengefektifkan komunikasi pembelajaran.

Seperti yang telah disarankan Richmond, untuk meningkatkan efektifitas komunikasi pembelajaran, guru di SMK BPP pun melakukan hal tersebut. Mulai dari mengalokasikan waktu yang tersediauntukmenyampaikan materi utama dan sebagian lainnya untuk mengulang baik kepada seluruh siswa ataupun secara individual kepada siswa ABK. Memberikan contoh secara langsung dengan proses yang menyenangkan, berdiskusi, tanya jawab diselingi cerita-cerita humor untuk menarik perhatian semua siswa terutama siswa ABK. Atau menyisipkan ceritacerita yang bisa memotivasi siswa untuk bisa melaksanakan semua tahapan instruksional yang dilakukan. Salah satu yang peneliti lihat adalah sisipan cerita chef ternama, seperti chef Juna atau chef Aiko yang suatu saat bisa juga diraih oleh para siswa di SMK BPP.

Dikaitkan dengan teori konvergensi simbolik, di sini guru membuat sebuah cerita retorik yang mampu membangkitkan motivasi dan kohesifitas kelompok. Baik itu siswa ABK maupun siswa nonABK termotivasi melalui cerita-cerita yang disampaikan guru dalam proses komunikasi pembelajaran yang berlangsung di kelas. Cerita yang disampaikan guru sebagai komunikator di dalam proses komunikasi pembelajaran ini menimbulkan ketertarikan dan semangat dari anggota kelompok. Hingga menimbulkan sebuah rantai fantasi ketika komunikator melontarkan cerita seorang chef terkenal, anggota kelompok yakni siswa juga melontarkan cerita terkait sebuah ajang chef, yang kemudian ditanggapi lagi oleh siswa lainnya dengan cerita berbeda lainnya dan begitu seterusnya.

Alasan sekolah melaksanakan komunikasi pembelajaran yang menggabungkan siswa $\mathrm{ABK}$ dan non $\mathrm{ABK}$ dari hasil wawancara yang dilakukan peneliti terhadap beberapa 
informan, terdapat beberapa alasan yang melatarbelakangi SMK BPP memilih inklusi atau menggabungkan proses komunikasi pembelajaran antara siswa $\mathrm{ABK}$ dan nonABK. Salah satu alasan yang mendasarinya adalah tujuan sosial yang juga menjadi salah satu dasar pendirian awal SMK BPP.

Berdasarkan wawancara dengan Kepala SMK BPP Tati Rusmiati, di awal pendiriannya di 1979, SMK BPP hanya memiliki dua jurusan, yakni tata boga dan busana. Tujuh tahun berjalan, SMK BPP beroperasi seperti halnya SMK lainnya kala itu. Tak ada siswa ABK yang masuk ke SMK BPP hingga pada 1986, atas rujukan salah satu ketua yayasan BPP, sekolah menerima seorang siswa $\mathrm{ABK}$ tuna rungu. Sejak pertama kali menerima $\mathrm{ABK}$, proses pembelajaran sudah disatukan antara siswa ABK dan nonABK. Mulai dari situ, setiap tahun selalu ada siswa ABK yang mendaftar. Namun terbatas hanya satu atau dua siswa.

"SMK BPP didirikan pada 1979 dengan dua jurusan, Boga dan busana, sejalan berjalannya waktu pada 1986 ada salah satu murid tuna rungu atas rujukan ketua yayasan. Yayasan menekankan, bahwa siapapun yang mau sekolah di sini harus diterima walaupun bentuknya seperti apapun, berdasarkan hal itu kami tidak menutup bagi anak-anak yang mau sekolah disini. Indah, murid ABK pertama kami di 1986, menjadi cikal bakal sekolah inklusi,", 8

Mendidik Indah menjadi keberhasilan tersendiri bagi pihak sekolah. Sebab ternyata Indah mampu mengikuti pelajaran bahkan melebihi ekspektasi guru dan pihak sekolah. Indah yang masuk di jurusan tata busana berhasil membuktikan bahwa siswa ABK mampu bersaing dengan siswa nonABK. Beragam karya busana berhasil dibuat. Bahkan setelah menyelesaikan studinya di SMK BPP Indah menjadi seorang desainer. Kini alumni ABK pertama SMK BPP ini menetap di Surabaya dan telah mempekerjakan puluhan karyawan yang juga memiliki keterbatasan atau disabilitas.

Keberhasilan pihak sekolah mendidik dan memandirikan Indah menjadi motivasi tersendiri bagi pihak sekolah. Apalagi setelah

\footnotetext{
${ }^{8}$ Wawancara Tati Rusmiati di SMK BPP 9 Februari 2015
}

lulus dari SMK BPP, alumni ABK pertama SMK BPP ini menjadi desainer yang berhasil. Ini kemudian memotivasi sekolah, yayasan, dan para guru untuk mempertahankan kebijakan inklusi di SMK BPP.

Meski sejak 1986 telah menerima siswa $\mathrm{ABK}$, namun pihak sekolah tidak pernah mengumumkan secara terbuka kepada masyarakat bahwa SMK BPP adalah sekolah inklusi. Informasi mengenai diperbolehkannya siswa ABK bersekolah di SMK BPP hanyalah informasi dari mulut ke mulut. Terutama di kalangan orang tua yang anaknya memiliki keterbatasan. Mereka yang mendaftar dan bersekolah di SMK BPP pada umumnya mengetahui informasi tersebut dari sekolah asal, teman, tetangga, dan orang-orang terdekat. Sekolah pun awalnya tak tahu apa itu inklusi. Yang dilakukan hanyalah membuka kesempatan seluas-luasnya kepada semua anak tanpa kecuali agar semua siswa bisa mendapat hak pendidikan yang sama.

Alasan sosial dan tidak membeda-bedakan siswa dari latar belakang memang menjadi hal yang ditekankan oleh yayasan BPP, tempat SMK BPP bernaung. Bahkan ketika pertama kali meminta sekolah untuk menerima siswa ABK tunarungu Indah, sekolah menekankan bahwa apapun dan bagaimanapun kondisi anak, asalkan dia mau sekolah di SMK BPP, harus diterima. Sebab ordinat dari pendirian SMK BPP dan yayasan BPP adalah pendidikan dan sosial. Seperti yang diungkapkan oleh Ketua Yayasan Bidang Pendidikan, Sofia Kartawidjaya.

". . ordinatnya pendidikan dan sosial, jadi kita membantu orang yang tidak mampu, makanya kita sejak lama menerima siswa dalam kondisi apapun. Karena menurut kami anak-anak yang tidak terlalu parah bisa disatukan belajarnya dengan anak regular, karena nantinya perkembangan siswa $\mathrm{ABK}$ dalam bersosialisasi jauh lebih cepat jika digabungkan" 9

Berdasarkan hasil wawancara dengan beberapa informan yang terlibat dalam pelaksanaan pendidikan inklusi di SMK BPP, peneliti melihat bahwa program ini dilatarbelakangi demi kepentingan tiga pihak. Yakni siswa ABK, organisasi yakni pihak yayasan dan

\footnotetext{
${ }^{9}$ Wawancara Sofia di SMK BPP 19 Maret 2015
} 
sekolah, serta siswa nonABK

Latar belakang dilaksanakannya komunikasi pembelajaran yang menyatukan siswa ABK dan nonABK di SMK BPP melihat bahwa Anak Berkebutuhan Khusus memiliki hak sama untuk mengenyam pendidikan. Peneliti melihat setidaknya ada tiga poin latar belakang dengan kepentingan ABK dalam implementasi pendidikan inklusi di SMK BPP ini. Memberikan kesempatan siswa ABK untuk mengenyam pendidikan formal di sekolah umum dan bersosialisasi dengan siswa normal melalui pembelajaran di kelas dan guru yang sama. Meningkatkan kualitas hidup ABK dengan memberikan skill kepada ABK agar siswa $A B K$ ini setidaknya mampu mandiri atau menghasilkan karya. Alasan sosial pihak sekolah untuk membantu anak-anak istimewa ini agar tidak terlantar dalam hal pendidikan di tengah stigma negatif $\mathrm{ABK}$ terutama di sekolah umum dan di tengah keterbatasan jumlah Sekolah Luar Biasa.

Organisasi yang peneliti maksud adalah pihak sekolah yakni SMK BPP sebagai penyelenggara pendidikan inklusi. Sebab penyelenggaraan komunikasi pembelajaran yang menggabungkan siswa $\mathrm{ABk}$ dan nonABK di SMK BPP ini berawal dari inisiatif pihak sekolah dan yayasan untuk menerima siswa ABK. Ada tiga poin yang bisa diuraikan berdasarkan hasil wawancara dengan beberapa informan. Mewujudkan tujuan sosial dari pendidikan inklusi ini untuk membantu anakanak yang kesulitan mencari sekolah mengingat masih terbatasnya sekolah inklusi dan SLB. Permintaan yayasan untuk menerima semua siswa tanpa kecuali menjadi tantangan bagi sekolah terutama guru mengingat tidak satupun guru di SMK BPP berlatar belakang Pendidikan Luar Biasa. Keberhasilan mendidik Indah, siswa ABK pertama yang diterima SMK BPP atas permintaan yayasan menjadi motivasi bagi sekolah untuk bisa mendidik ABKABK lainnya yang membutuhkan layanan pendidikan inklusi.

Meski penyelenggaraan inklusi awalnya dilatarbelakangi untuk mengakomodir anak-anak berkebutuhan khusus, namun dalam perjalanannya pihak sekolah justru mendapati bahwa dengan disatu-kannya proses belajar antara siswa $\mathrm{ABK}$ dan nonABK, bukan hanya siswa $\mathrm{ABK}$ yang mendapat manfaat. Siswa
nonABK pun menerima manfaat lain dari penyelenggaraan sistem pendidikan ini. Peneliti melihat ini juga sebagai salah satu latar belakang yang memperkuat sekolah untuk melanjutkan penyelenggaraan pendidikan inklusi. Setidak-nya ada tiga poin yang bisa diuraikan. Pendi-dikan karakter otomatis tertanam di kalangan siswa nonABK karena sejak awal masuk di SMK BPP, siswa nonABK dituntut harus mengerti, dan berempati kepada siswa ABK. Meningkatkan sifat religi bagi siswa nonABK dengan selalu bersyukur terhadap apa yang diberikan Tuhan dan apa yang dimiliki oleh diri siswa $\mathrm{ABK}$ tanpa kekurangan apapun. Meningkatkan sikap toleransi karena dengan disatukannya belajar mengajar di kelas yang sama, maka siswa nonABK yang menjadi teman sekelasnya harus memiliki toleransi lebih.

Latar belakang dilaksanakannnya layanan inklusi di SMK BPP dapat digambarkan dalam bagan sebagai berikut:

Yayasan pendidikan BPP merupakan yayasan pendidikan swasta yang bersifat komersil karena tidak dibiayai negara. Namun demikian hal ini tak menutup SMK BPP untuk melaksanakan aktivitas sosial dalam menjalankan perannya sebagai lembaga pendidikan. Ordinat sosial dan pendidikan yang sejak awal menjadi latar belakang pendirian yayasan pendidikan ini menjadi alasan SMK BPP untuk membuka layanan inklusi yang memberikan kesem-patan bagi siapapun tanpa kecuali untuk bisa mengenyam pendidikan kejuruan. Dengan layanan inklusi ini berarti siswa $\mathrm{ABK}$ dan nonABK melaksanakan seluruh proses dalam kelas yang sama di waktu yang sama alias digabungkan.

Alasan sosial inilah yang menjadi latar belakang utama dibukanya layanan inklusi di SMK BPP hingga akhirnya ditunjuk secara resmi oleh dinas pendidikan. Terlepas dari segala kekurangan penyelenggaraan layanan inklusi di SMK BPP, dengan pembukaan layanan inklusi ini hak pendidikan diterima oleh semua anak termasuk anak-anak ber-kebutuhan khusus. Akses anak-anak berke-butuhan khusus menjadi semakin terbuka di tengah keterbatasan sekolah luar biasa dan minimnya layanan sekolah inklusi di SMK.

Pelaksanaan komunikasi pembelajaran dengan cara menggabungkan siswa $\mathrm{ABK}$ dan nonABK di SMK BPP awalnya hanya bertujuan 


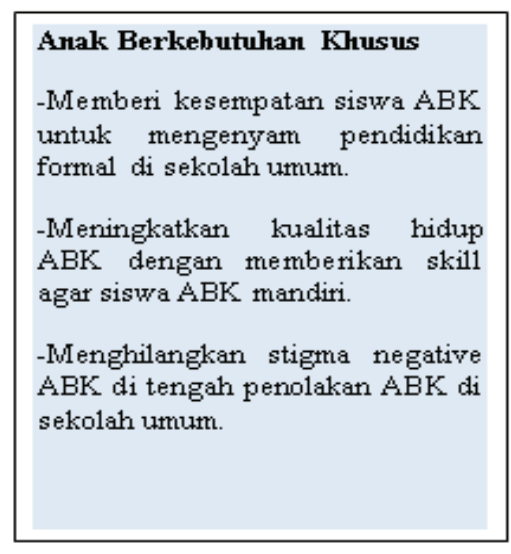

Sumber: Data hasil penelitian, 2016

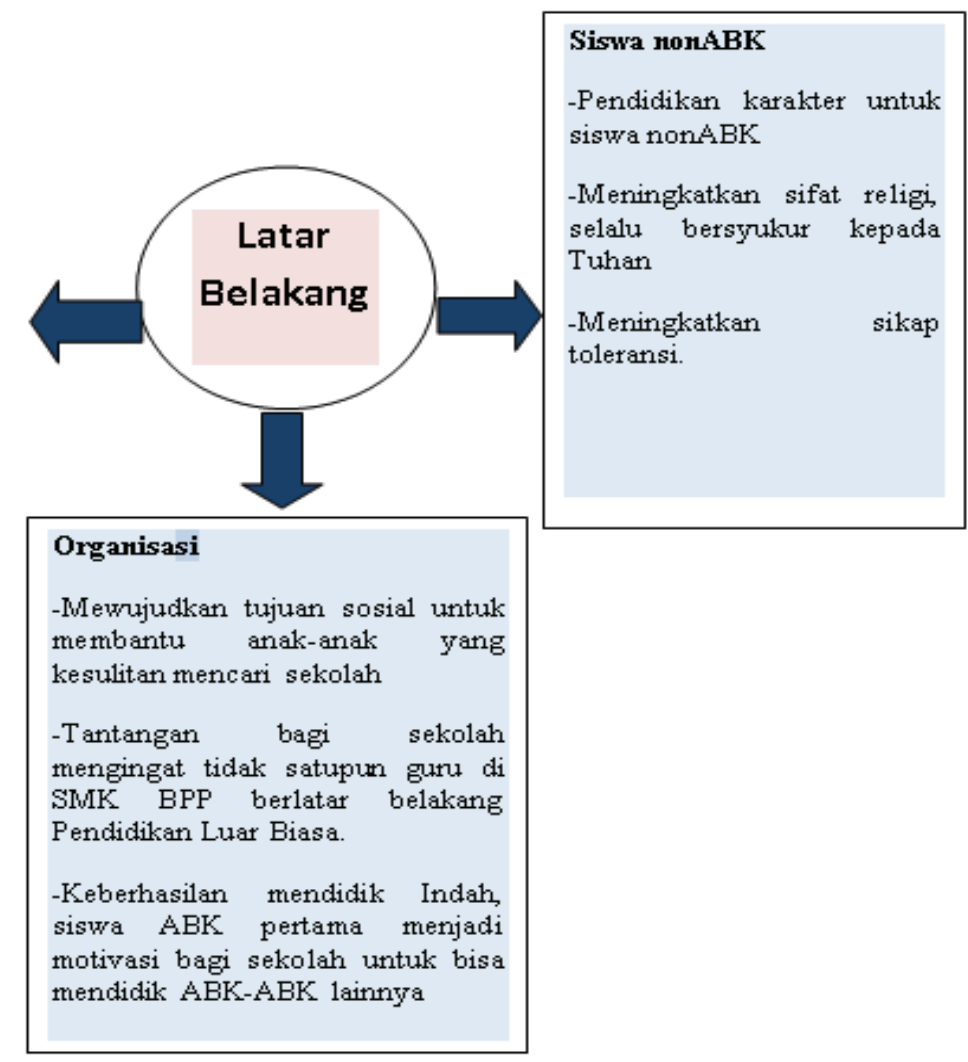

\section{Gambar 3 Latar Belakang Penyelenggaraan Layanan Inklusi}

untuk mengakomodir kebutuhan anak dengan kebutuhan khusus. Sekolah berpandangan bahwa semua anak memiliki hak pendidikan yang sama apapun kondisi anak tersebut. Tak hanya itu, sekolah juga memiliki prinsip bahwa layanan inklusi yang diberikan kepada masyarakat harus terjangkau bahkan bagi anak-anak yang tidak mampu, sekolah tetap memberikan kesempatan belajar.

Layanan inklusi berarti layanan yang mengakomodasi kebutuhan pendidikan semua anak bangsa tanpa menghiraukan kondisi fisik, intelektual, sosial, emosional, bahasa, dan kondisi lainnya. Pendidikan inklusif merupakan realisasi dari komitmen education for all, yang dicanangkan Unesco di Thailand 1990.

Berdasarkan wawancara dengan sejum-lah narasumber dalam penelitian ini di antaranya pihak yayasan, pihak sekolah yakni guru dan kepala sekolah serta dari pihak dinas pendidikan, alasan penyelenggaraan komunikasi instruksional dengan meng-gabungkan siswa $\mathrm{ABK}$ dan nonABK ini terkait dengan tiga faktor kepentingan. Yakni siswa ABK, siswa nonABK, dan organisasi yakni sekolah beserta seluruh seluruh tenaga pengajarnya.

Latar belakang kepentingan ABK dapat dilihat dengan teori interaksi simbolik di mana George Herbert Mead mencetuskan tiga konsep mendasar yakni mind, self, and society. Tiga konsep ini saling mempengaruhi satu sama lain dalam interaksi simbolik (dalam West and Turner, 2009).

Implementasi layanan inklusi di SMK BPP menurut teori interaksi simbolik yang diungkapkan Mead (dalam West and Turner, 2009) dimulai dengan pikiran (mind) bahwa layanan inklusi mempunyai tujuan untuk memberikan kesempatan yang sama kepada ABK untuk mengenyam pendidikan. ABK dianggap sebagai anak yang juga mampu mandiri dan memiliki skill seperti anak-anak lainnya. ABK juga dianggap mampu mengikuti proses pembelajaran di kelas bersama-sama dengan siswa nonABK. SMK BPP sebagai sebuah institusi yang didalamnya ada guru atau self yang melakukan sebuah kegiatan interaksi dalam sebuah proses komunikasi instruksional guru di kelas di mana ada siswa ABK dan nonABK di dalamnya. Siswa ABK diakui keberadaannya bahkan dianggap sama dengan siswa nonABK karena di sekolah tak ada perbedaan, semua fasilitas, guru, termasuk kurikulum disamakan antara siswa $\mathrm{ABK}$ 
dan nonABK. Di sini kepercayaan diri anak ditingkatkan sehingga konsep diri anak pun menjadi semakin baik. Konsep diri yang baik dimulai dari pemahaman tentang kekuatan dan kelemahan diri serta keyakinan bahwa kemampuan diri dapat ditingkatkan.

Sementara itu dikaitkan dengan teori konvergensi simbolik, peneliti melihat bahwa sejak awal kebijakan SMK BPP untuk menjadi sekolah inklusi, pihak sekolah dan yayasan telah menciptakan realitas bersama bagi seluruh warga sekolah. Mulai dari guru, juga siswa nonABK beserta orang tuanya. Realitas mengenai keberadaan siswa ABK di sekolah dan berbagai kemungkinan yang dihadapi diciptakan melalui komunikasi. Sejak siswa mendaftar dan berniat sekolah di SMK $\mathrm{BPP}$, siswa beserta orang tua nonABK diberi pengertian mengenai keberadaan siswa $A B K$ di sekolah tersebut. Dalam hal ini komunikasi menciptakan realitas melalui pengaitan antara kata-kata yang digunakan dengan pengalaman atau pengetahuan yang diperoleh. Di sini terjadi konvergensi (penyatuan) hingga menjadi realitas bersama dan semua yang ada di sekolah menjadi terbiasa dengan berbagai kejadian, simbol, dan tingkah laku siswa ABK yang bagi orang lain yang baru masuk ke SMK BPP terlihat sebagai peristiwa aneh.

\section{SIMPULAN}

Beberapa kesimpulan yang bisa ditarik adalah: (1) Faktor yang mempengaruhi pola komunikasi guru pada siswa $\mathrm{ABK}$ di kelas di antaranya kompetensi dan kemampuan komunikasi guru, kesiapan siswa, dukungan lingkungan, serta orang-orang di sekitar ABK seperti helper dan orang tua juga menjadi faktor lainnya. (2) Komunikasi instruksional guru dilakukan melalui beberapa saluran dan metode. Mulai dari komunikasi di depan kelas dengan metode ceramah, diskusi kelas, dan tanya jawab, serta komunikasi instruksional secara individual dengan berbagai teknik komunikasi. Penggunaan tutor sebaya dilakukan untuk mengefektifkan pembe-lajaran. Penggunaan bahasa verbal dan nonverbal seperti raut muka ekspresif, suara lantang, artikulasi jelas, gaya tubuh dan bahasa tubuh ekspresif, disertai dengan sentuhan, belaian, tatapan mata. (3) Penyelenggaraan pendidikan inklusi yang menggabungkan siswa $\mathrm{ABK}$ dan
nonABK di SMK BPP Bandung dilaksanakan demi kepentingan tiga pihak. Yakni siswa ABK, organisasi yakni pihak yayasan dan sekolah, serta siswa nonABK.

Saran praktis yang peneliti berikan berdasarkan hasil penelitian ini antara lain: (1) Penambahan fasilitas penunjang dan fasilitas khusus bagi siswa ABK untuk menunjang proses belajar mengajar di kelas, (2) Perlu penyediaan tenaga ahli di sekolah dan ruangan khusus agar siswa ABK tidak terkesan 'liar' di sekolah, (3) Keberadaan helper atau pendamping lebih dimanfaatkan dengan baik, tidak hanya bertugas mengawasi tanpa punya kewenangan terlibat dalam kurikulum. Sedangkan saran ilmiah yang peneliti berikan yaitu diperlukan penelitian lanjutan yang bisa melihat efektivitas dari komunikasi instruksional guru pada siswa ABK.

\section{DAFTAR PUSTAKA}

Creswell, J. W. (2007). Qualitative inquiry and research design choosing among five approaches. California: Sage Publications.

Griffin, E. M. (2012), A first look at communication theory international edition. Boston: McGraw Hill Higher Education.

Infacte, D. A., Rancer, A. S. , \& Womack, D. $\mathrm{F}_{\text {. }}(1993)$. Building communication theory. Illinois: Waveland Press Inc.

Jamaris, M. (2013). Orientasi baru dalam psikologi pendidikan. Jakarta. Ghalia Indonesia.

Littlejohn, S. W. \& Foss, A. K. (2008). Theories of human communication. Belmont: Wadsworth.

McCroskey, J. C. Valencic, K. M. \& Richmond, V. P. (2004). Toward a general model of instructional communication. Communication Quarterly, Vol 52 No 3.

Nimmo, D. (1979). Communication year. book 3. New Jersey: The International Communication Assosiation.

Raymond W. P. \& Wheeless, L. R. (2014). Perspectives on Instructional Communication's Historical Path to the Future. Communication Education Vol. 63, No. 4, Oktober 2014, pp. 308-328.

Venus, A. (2007). Ernest Bormann dan Teori Konvergensi Simbolik (Symbolic Convergence Theory). Jurnal ISKI, Volume 1, No 1, Agustus 2007.

West, R. \& Turner, L. H. (2009). Pengantar teori komunikasi anatisis dan aplikasi. Jakarta: Salemba Humanika.

Yusup, P. M. (1990). Komunikasi pendidikan dan komunikasi instruksional. Bandung: Remaja Rosdakarya. 